\title{
Aboriginal sentencing in Western Australia in the late 19th century with reference to Rottnest Island prison
}

\author{
Neville Green \\ 182/85 Hester Ave, Merriwa, Western Australia 6030, Australia. \\ Email: marnev18@y7mail.com
}

\begin{abstract}
Between 1841, when Rottnest Island was proclaimed a legal prison exclusively for Aborigines and the Aborigines Act, 1905, at least 18 Acts and amendments were proclaimed to protect, employ and punish Aboriginal people in Western Australia. This paper considers several of the laws passed after 1870, the manner of policing and sentencing in the northern districts of the colony and the transfer of those convicted under these laws to Rottnest Prison. The application of sentencing laws in the Gascoyne, Upper Gascoyne and Upper Murchison is considered in some detail because in 1884, the number of Rottnest prisoners originating from these districts exceeded the totals from all other districts in the colony. This in turn raises a question whether the number of prisoners originating from these districts may be attributable to an abnormally high rate of criminal acts or to the harsh judgements of those hearing the charges.
\end{abstract}

KEYWORDS: policing, Murchison, Gascoyne, legislation

\section{INTRODUCTION}

In the early 1980s, the Australian Institute of Aboriginal Studies funded a research project leading to the publication of what was expected to be a single biographical dictionary of Western Australian Aborigines to complement the settler, convict and Asian volumes compiled under the supervision of Dr Rica Erickson and published by the University of Western Australia Press. Sylvia Hallam, Ken Colbung, Bob Reece, Lois Tilbrook, Neville Green and later Anna Haebich, comprised the Aboriginal dictionary committee that engaged and supervised university student researchers. The research team examined the files of the Colonial Secretary's Office (CSR) from 1829 to 1887 and the major Western Australian newspapers from 1833 to 1890 . Funding was exhausted by 1984 and volunteers continued with the Colonial Secretary's records but did not attempt the equally mammoth holdings of the Police, Prisons and Aborigines Departments. Every Aboriginal name seen was carded with individual particulars and typed into 26 volumes, copies of which are held at the Battye Library of Western Australian History. Four Aboriginal volumes were published: Vol. VI, Aborigines of the Albany Region 1821-1898 (Neville Green); Vol. VII, Aborigines of New Norcia 1845-1914,
(Green and Lois Tilbrook); Vol. VIII, Aborigines of the Southwest Region 1829-1840, (Sylvia Hallam and Tilbrook); and Vol. X, Far From Home: Aboriginal Prisoners of Rottnest Island 1838-1931, (Green and Susan Moon, later Susan Aguiar). Additional funding in 1990 enabled Green and Moon to collate and type the unpublished names into three volumes: 'Aboriginal Names of the South West c. 18411890; Aboriginal Names of the Murchison c. 1848-1890 and, in one volume, Aboriginal Names of the Pilbara $c$. 1870-1890; the Gascoyne c. 1880-1890; the Kimberley c. 1880-1890.

These volumes have proved an invaluable resource for Native Title research in Western Australia (Peter Sutton, pers. comm.). There is no doubt that the detailed and meticulous study by Hallam and Tilbrook was a key source in the Noongar claim over the City of Perth (Bennell v State of Western Australia 2006), while the series as a whole revealed for Native Title researchers the unsuspected volume of primary sources in the State archives.

This paper picks up a theme identified in Far from Home: Aboriginal Prisoners of Rottnest Island 18381931, exploring in general terms the arrests and sentencing of Aboriginal men for stock crimes and absconding in the northern pastoral districts during 
the last decades of the 19th century and showing how the changes to legislation during this period affected patterns of Aboriginal imprisonment on Rottnest Island.

Rottnest Island, now a popular tourist destination, lies $20 \mathrm{~km}$ off the coast of Western Australia and is clearly visible from Fremantle. It received its first prisoners in 1838 and formally came into existence as a prison with the 1841 Act to Constitute the Island of Rottnest as a Legal Prison. The Aboriginal prison officially closed in 1902 but the following year it became an annex of Fremantle prison and, until 1931, received Aboriginal and nonAboriginal low risk prisoners to do maintenance work on the tourist holiday cottages, roads and pathways. Between 1838 and 1931, more than 3,670 Aboriginal men served one or more sentences on the island and 365 are buried there.

The 1850 land regulations provided for pastoral leases to a maximum of 20,000 acres and the lease was extended from one year to eight years, still six years less than in New South Wales. At the insistence of Earl Grey of the British Colonial Office, after 1851 the form of lease included a clause giving Aborigines a right of access to pastoral leases to seek their subsistence, a right which continues to the present (Western Australian Government Gazette, 17 December 1850). New land regulations in 1864 raised the maximum lease area to 100,000 acres and offered a generous rent concession to those willing to pioneer new districts of the North-West (Western Australian Government Gazette, 24 August 1864, VIII, para. 1-7). This inevitably brought settlers into conflict with Aboriginal people on an expanding pastoral frontier (Figure 1). Thomas and Stewart (1978), in their study of imprisonment in Western Australia, argued that in the early years settler fear of Aborigines influenced the arrests but later in the century fear gave way to a 'dislike of the native population' and eventually to contempt, shown in the lack of compassion. They noted, 'very rarely in the history of the legislature is there a categorical denunciation of the conditions under which Aborigines were imprisoned' (1978: 121-122).

During the collation of data for Far from Home it became apparent that the advance of the pastoral frontiers between 1854 and 1900 was reflected in the Rottnest prison population. For example, the overall preponderance of prisoners from the SouthWest reflects the early establishment of pastoral settlement in that region (Figure 2). Similarly, stock killing was by far the commonest conviction. There was a marked increase in the number of prisoners sent to Rottnest from the 1860s, as the pastoral frontier expanded, especially following the 1864 regulations and their incentives (Figure 3). This reached a striking peak in the 1880 s. Closer inspection of the data showed that in 1884

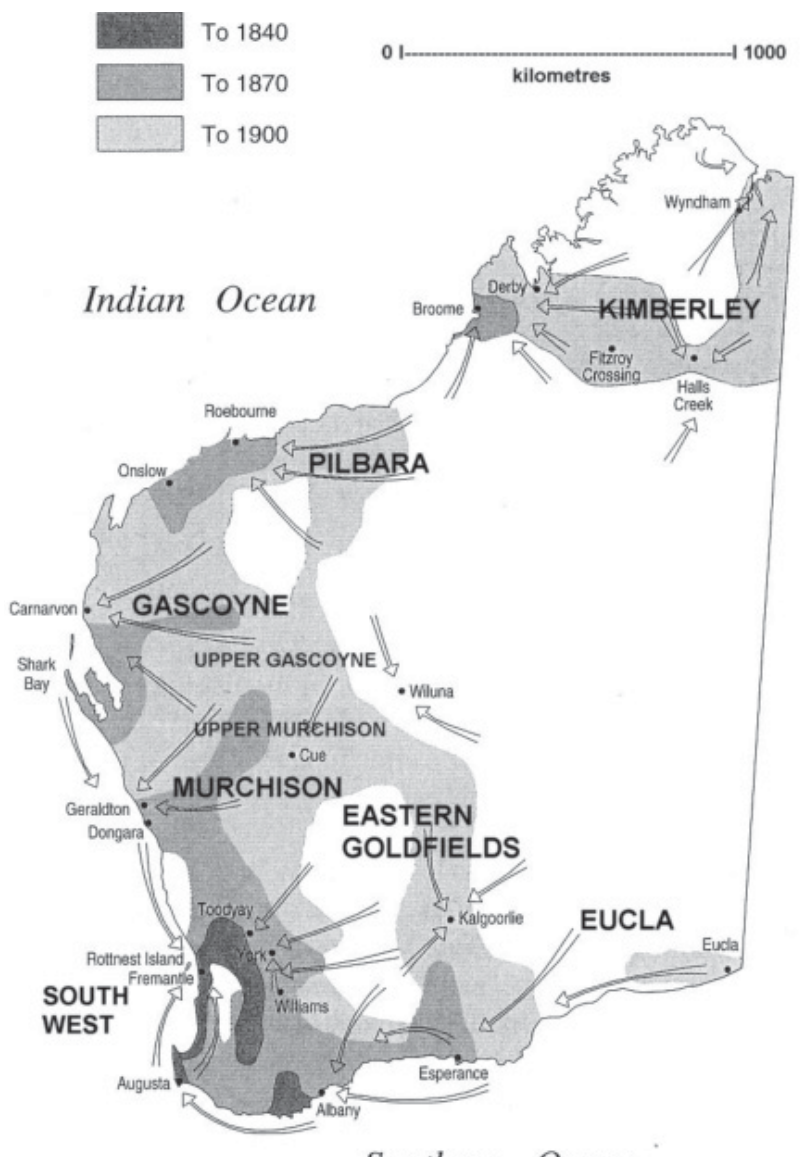

FIGURE 1 Major regions of Western Australia and the spread of settlement. The arrows indicate the general patterns of movement of Aborigines in custody from point of arrest to trial venue to Rottnest.

for example, prisoners from the Murchison and Gascoyne regions accounted for more than half of the Rottnest prisoners, with the most convictions for stock killing (Figure 2, Table 1). This paper considers the circumstances in the Murchison and Gascoyne regions that account for this pattern.

\section{ABORIGINES, POLICING AND SENTENCING IN THE 19TH CENTURY}

\section{POLICING ON THE FRONTIERS}

Previous authors discussing aspects of Aborigines and policing in Western Australia during the late 19th century include: Roth (1905), Gill (1977), Thomas and Stewart (1978), Pedersen and Woorunmurra (1995), Green (1995), Owen (2003) and Pashley (2000). Collectively, they provide an overview of the location of police stations in Western Australia and the role of police in the pursuit and arrest of Aboriginal suspects, especially in the Kimberley region. McCorquodale (1987) offers a summary of legislation applicable 
TABLE 1 Home districts, offences and sentences of prisoners at Rottnest, December 1884.

HOME DISTRICTS

OFFENCES

SENTENCES

\begin{tabular}{lcllll} 
South-West & 22 & Stock Killing & 71 & $<1$ year & 7 \\
Murchison & 8 & Larceny & 17 & 1 year & 44 \\
Upper Murchison & 37 & Tribal Murder & 14 & 2 years & 10 \\
Gascoyne & 37 & Tribal Assualt & 7 & 3 years \\
Pilbara & 7 & Settler Murder & 1 & 6 years & 34 \\
Kimberley & 2 & Settler Assualt & 2 & $7-10$ years & 3 \\
& & Absconding & 1 & $>10$ years & 3 \\
& & & & Life & 8 \\
\hline
\end{tabular}

to Aborigines in Western Australia and Russell (1980), in her history of law in Western Australia, devotes a chapter to the application of these laws to the Indigenous population. Published discussion about policing and Aboriginal offending in the Murchison-Gascoyne districts is more limited than in the Kimberley. Pilmer (1998) and Morrow (1937), both former police officers, include some comment in their autobiographies, but this is not discussed in this paper which draws mainly on archive material.

\section{THE KIMBERLEY REGION}

The accounts of policing in the Kimberley in the late 19th century reveal a number of disturbing trends which have relevance for other districts to the south. Royal Commissioner Walter Roth (1905: 5) accused the police of indiscriminately arresting Aborigines merely to pad their pockets with the ration allowance and noted that an escorting officer paid the per capita ration allowance of two shillings and sixpence per day could double his salary. The constables and the Aboriginal police assistants in search of offenders were armed and carried chains for at least 15 prisoners. Roth noted 'To secure a conviction the accused are accordingly made to plead guilty - at the muzzle of the rifle, if need be' (Roth 1905: 15) and reported that one constable, who admitted bringing about 100 Aborigines to court, 'does not remember any who have been found "not guilty"' (Roth 1905: 16). It is likely that a similar situation existed in the Gascoyne



FIGURE 2
Districts of origin of prisoners at Rottnest over the total life of the prison and in December 1884.



FIGURE 3
Number of prisoners received at Rottnest in each decade. 
and Murchison districts where the accused were not represented in court and there was rarely an attempt to prove the charges, validate the alleged confessions or challenge witnesses, often women related to the accused. ${ }^{1}$

In 1887, the lessee of La Grange station reported that Aborigines had stolen about 900 sheep. Constable Best and his assistants arrested 41 men and women and walked them overland to Roebourne, more than $500 \mathrm{~km}$ to the south (Police 1590/1887). Colonel Angelo heard the charges and, noting the emaciated condition of the prisoners, suggested that a feeding depot might be more appropriate than a courtroom. All the prisoners confessed to killing stock: 'We did kill the sheep and we eat them because we were hungry. We will be satisfied to work here if we are fed' was the explanation given by one of the northern prisoners. The sentences of the La Grange group varied. One man received two years; eight men were given 18 months and the rest six months each. The women and the short-term prisoners were retained at Roebourne and the others, including Caramul @ Puidar, were sent a further 1,500 km south, arriving at Fremantle on 19 November 1887 (CSR 4465/1887). The prisoners were confined at the Round House prison at the end of High Street, where they were examined by a medical officer before the transfer to Rottnest where Superintendent Timperley discovered that not one of the La Grange men answered to the names on their documents. 'I had great difficulty in identifying them,' he wrote, and suggested that a prisoner's description be included on the back of the warrant bearing his name (CSR 4170/1887).

\section{THE MURCHISON AND GASCOYNE REGIONS}

The arrival of Yallingah No. 728 at Rottnest in 1877 to serve six months for spearing sheep marks the beginning of the trail of men from the Upper Murchison and Upper Gascoyne. The reason why so many prisoners were sent from this relatively small region is explained by the harsh terms of the legislation and an over-zealous prosecution of the law by three Justices of the Peace, Everard and Leonard Darlot and Edward Bush, and one magistrate, C.D. Foss. The Murchison and Gascoyne Rivers originate near the Robinson Ranges and flow some $500 \mathrm{~km}$ west to the Indian Ocean (Figure 4). The Robinson Ranges dominate the geography of the upper reaches of these two rivers and provide a watershed for the many small creeks that flow north into the Gascoyne and those that turn south



FIGURE 4 The Upper Gascoyne and Upper Murchison regions.

and south-west into the Murchison. Mt Gould on the south-western corner of the range overshadows Gould Creek that continues past Beringarra homestead to the Murchison. Errabiddy homestead, less than $80 \mathrm{~km}$ north of Beringarra, sits within sight of the western edge of Robinson Ranges, near Black Adder and Bubbagundi Creeks which flow north into the Upper Gascoyne. Closer to the Gascoyne River are Mt Clere and Mt Labouchere and the police stations and homesteads that bear those names. According to Tindale's (1974) mapping of tribal boundaries, this is the province of the Wadjari, Nganawonka, Ngarla and Madoitja language groups. During the 1880s, prisoners arriving at Rottnest Island from this small region exceeded the combined totals from the Pilbara, Kimberley and South-West (Figure 2, Table 1).

In 1881, 21-year-old Everard Darlot took up Beringarra station on his father's behalf and the following year was joined by his younger brother Leonard. Both were appointed Justices of the Peace and sentenced many of the Aborigines charged with stock crimes in the district. When the pastoralists like the Darlots took up leases in the Upper Murchison, police from Yalgoo had the arduous task of patrolling a district the area of Tasmania. Mt Wittenoom police station (1880-1912) west of Cue was a second base for northern patrols before Beringarra police station opened in $1886^{2}$ and Mt Gould station and lockup was constructed in 1888. Police from Mt Labouchere and Mt Clere police stations on the northern side of the Robinson Ranges occasionally brought prisoners to Mt Gould or Beringarra and police joined forces to track down offenders; as noted in the Beringarra

\footnotetext{
${ }^{1}$ In October 1888, on the Upper Gascoyne, Inspector Troy met with four constables and an Aboriginal assistant with 11 men on neck-chains and eight female witnesses accompanying the patrol (CSR 827/1889). The women presumably foraged along the route to supplement the prisoners' rations.

${ }^{2}$ Acc 527, CSO 1882, SROWA, Troy's report, 31 January 1882 and P.C. Smith 18 February 1882.
} 
police station occurrence book on 5 February 1885: 'PC Houlahan and Eaton arrived here at noon to assist in nigger hunting.' (Beringarra Police Station Bush Occurrences).

In 1883, Superintendent W.D. Jackson recorded his surprise when 38 prisoners, naked but for a waist belt with pieces of gunny sack as pubic covers, were landed at Rottnest. These men took the prison population to 176 , well above its capacity of 106. Overcrowding no doubt contributed to the high toll of deaths in custody that year; this prompted Governor Broome to appoint John Forrest as Commissioner to examine the conditions of Aboriginal prisoners (Forrest 1884). A new superintendent, W.H. Timperley, implemented many of Forrest's recommendations but the number of prisoners arriving from the recently settled pastoral regions of the North-West continued to increase.

A Justice of the Peace might sentence those convicted to a prison term on Rottnest or remand the accused men for trial before a magistrate. Either way they were chained and then escorted to the coastal ports of Carnarvon or Geraldton. On 20 August 1885, Constables Smith and Eaton with three Aboriginal assistants left Beringarra with 24 prisoners for the port of Geraldton. Their route was via Murgoo, Wittenoom and Yuin stations and the town of Mullewa, arriving at Geraldton on 1 September to await shipment to Rottnest. In February of the following year, the 33 prisoners disembarked at Fremantle included 28 from the Upper Gascoyne-Murchison. In June, 26 men were landed and in October, another 31 men from the Upper Gascoyne and four from the Murchison were received. In May 1887, Constables Smith, Payne and Donovan escorted 34 prisoners from the Upper Murchison to Carnarvon where four died of influenza shortly after their arrival and the others were destined for Rottnest (CSR 1126/1886, CSR 2712/1886, CSR 2171/1887).

When Itinerant Stipendiary Magistrate Charles Denroache Foss, a former farmer, pastoralist and sheep scab inspector, wrongly sentenced 69 Aboriginal men, Alex Onslow, the Administrator of the colony and the Attorney General summoned members of the Legislative Council to consider Foss' legal status. When the Council met on 16 April 1883, Stephen Parker asked that Colonial Secretary table papers relating to Robert Fairbairn ${ }^{3}$ who had sentenced 29 Murchison men to excessive terms of imprisonment on Rottnest Island (WA Parliamentary Debates, 16 April 1883, pp. 13-14). While his action was lauded in some quarters as necessary to put an end to the troubles, it was nevertheless illegal and to make amends the Legislative Council adopted a Natives Convictions Validity Bill to retrospectively to validate the sentences (WA Parliamentary Debates, 16 April 1883, pp. 15-18). Parker, however, reminded Members that magistrates throughout the colony had been illegally sentencing Aborigines to three years in prison and he hoped that 'philanthropic' efforts would be made to release all those illegally sentenced. In the months that followed, 23 men from the Gascoyne, 15 from the Upper Murchison, three from York and one from Roebourne were granted an early discharge 'by special warrant' (CSR 445/1885). The notation for eight of the prisoners has been struck out without explanation.

The validating legislation was followed in July 1883 by the Aboriginal Offenders Bill (WA Parliamentary Debates, 13-19 April and 18 July-8 September 1883). At the second reading on 3 August, the Attorney General, Alfred Hensman, explained that the laws for Aboriginal offenders had changed very little since 1849 when two justices, one being a protector or guardian, had the power to impose sentences not exceeding six months (WA Parliamentary Debates, 3 August 1883, p. 137). During the debate, Maitland Brown, a man who gained local fame in 1865 by recovering the bodies of Panter, Harding and Goldwyer who were murdered near La Grange, wanted to retain cumulative sentencing. Hensman replied that for 20 years magistrates had imposed cumulative sentences, the prisoner numbers had not diminished and it was now contributing to the overcrowding at Rottnest. The practice obviously was not working (WA Parliamentary Debates, 3 August 1883, p. 147).

The Aboriginal Offenders Act, 1883 (Section 4) allowed a magistrate 'together with one or more Justices of the Peace' to confine an offender 'for any term not exceeding two years' even when the accused was convicted of two or more crimes that may each carry a two years sentence. Two Justices, or one if none other was within 20 miles, were limited to maximum sentencing of one year. Edwin Rose JP ignored the limits in 1899 by sentencing six men each to six years gaol for killing one animal (CSR 684/1899). Foss continued to impose three year sentences on men convicted of sheep stealing and pastoralist JPs were equally severe (CSR 6141/1884 ${ }^{4}$ ). Table 1 shows the sentences of those held at Rottnest Prison in 1884. The one year sentences by JPs and the three year sentences imposed by Foss stand out clearly. In August 1884,

\footnotetext{
${ }^{3}$ Fairbairn was born at Picton, near Bunbury in 1841 and was home educated by his father. At 17 he took a position as a teacher in Perth and 4 years later accepted a job as a law clerk at Busselton and for 10 years before 1883, he served as the Government Resident at several towns in Western Australia. Fairbairn was appointed the Resident Magistrate for Derby in the Kimberley and Foss became the Resident Magistrate at Carnarvon. Foss sent more men to Rottnest Island than any other magistrate.

${ }^{4}$ This file gives the names of more than 60 men whose three year sentences were later reviewed by the Colonial Secretary.
} 
20 of the 22 prisoners received at Rottnest were sentenced by Leonard Darlot at Beringarra station. In October 1884, six men arrested at Errabiddy station were taken to Carnarvon where Foss gave each three years at Rottnest for breaking into a store (CSR 6164/1884). A disturbing feature of some of the convictions is the time elapsed between the alleged crimes and the trials. For example, Tangena, Nageting and Maraguroo were accused of stealing clothing and rations from a shepherd's hut in January 1882 and taking two lambs from Errabiddy station on 4 September 1882. They were tried by Foss more than two years after the alleged crime and each sentenced to three years at Rottnest ${ }^{5}$. Many of these men were incapable of distinguishing between an animal killed recently and the one for which they were now convicted and given the language barriers they may have had no understanding of the charges or of the sentences.

\section{INDENTURED EMPLOYEES}

Aboriginal men, women and children employed on pastoral stations fell within the bounds of the Masters and Servants Act ${ }^{6}$ and were 'signed


those associated with the original lease area were regarded as a form of 'property' owned by the pastoralist who signed up as many as possible to ensure sufficient labour for the busy shearing season. During the slack months the workers were sent into the bush to fend for themselves and if they didn't return they were considered to be 'absconders' and a warrant could be issued for their arrest. The warrant for the arrest of an absconder was not limited by time or distance and a man arrested on the outward journey of a patrol may remain on the chain for the duration of that patrol.

'Absconding' from an employer was a common charge and a JP could return the man to his master or impose a three month sentence. Rottnest was easy to access for Southern JPs and absconders account for about $10 \%$ of the Rottnest prisoners. In the north-west and remote areas absconding was regarded as a local issue and occasionally the employer was authorized to pursue the absconders. On 4 April 1879, Albert Rowse was sworn in as a special constable to hunt and arrest his 14 absconding 'servants'. Three months later, he brought 13 men before Roebourne Magistrate, Fred Pearse, who sentenced nine to the cells at Roebourne; four were sentenced to fourteen days and five to seven days and the others were discharged to the custody of Rowse (Police

\section{8/307/1879).}

In 1885, Governor Broome requested Resident Magistrates to report on the local employment practices and the returns reveal an ad hoc situation. Colonel Angelo of Roebourne replied that there were no agreements in the Pilbara because pastoralists claimed all the Aborigines on their land. Aborigines were assigned for life with no termination and no pay, only flour, tobacco and clothing (Angelo to Colonial Secretary, 6 April, 1886 CSR 542/1886). Foss, at Carnarvon, gave an opposing view, 'All Native servants in this district are engaged under the Masters and Servants Act - the natives enter the service of the settlers of their own free will ... I have never heard of a case of a native being kept in the service of a settler by means of compulsion or deceit ...' (Foss to Colonial Secretary, 29 September 1885 and 27 March 1886 CSR 4925/85). Dr Lovegrove at Derby reported that the written contracts were usually for a six month period and the employee was paid. This was contradicted by Fairbairn who stated that in the Kimberly contracts for 12 months were signed and witnessed and that the employees received flour, tobacco and clothing. In the Southern regions, at Newcastle (Toodyay), Busselton and Williams, verbal contracts were common, with men employed for 6 to 12 months as shepherds and servants with some paid in cash and others receiving goods in lieu of money. At Albany, contracts were written and payment, in money, reflected the nature of the tasks. Thus, despite the legal umbrella of the Masters and Servants Act, the employment practices were varied and generally unsupervised.

Broome introduced the Aborigines Protection Bill to regulate Aboriginal employment but the pastoralist dominated Legislative Council could not agree on a minimum age. Robert Sholl, with family interests in the pearling industry, objected to the minimum age being set at 16 years. As he explained: 'Now everyone that knew anything at all about these natives must know that it was between the ages of 10 or 12 and 16 that they were most useful' (WA Parliamentary Debates, 19 August 1886, p. 462). Merchant William Shenton wanted the age of Aboriginal employment reduced to 12 years, Wittenoom argued for 10, pastoralist McKenzie Grant claimed that children as young as seven or eight were employed to mind sheep and to watch the horses. Pearling master and pastoralist Alexander McRea agreed and did not consider a boy of ten too young to be bonded. A comment by grazier George Layman placed Aboriginal children on the same level as station foals, 'You can't commence too

\footnotetext{
${ }^{5}$ These three epitomize one of the puzzles of Rottnest research. The names appear in Foss's list but they are not amongst the Fremantle arrivals or on the 31 December list of Rottnest inmates and for this reason were omitted from Far from Home.

${ }^{6}$ The Imperial Masters and Servants Act and Breach of Contract Act were adopted c1842 and amended in reference to Aborigines in 1868, 1882,1886 and 1892.
} 
soon to break them in' (WA Parliamentary Debates, 30 August 1886, p. 557).

The Aborigines Act 1886 established a contract system $^{7}$ with the minimum age of employment at 14 years. An absconder could not be arrested beyond a 30 mile radius of the place where the warrant for his arrest was issued and this became a contentious issue. The maximum penalty for absconding remained at three months gaol. In August 1892, six years after a change in the law, Police Inspector Lodge reported that pastoralists in the Upper Murchison continued to sign up excessive numbers of Aborigines: 'the settler would still consider himself the rightful master of such natives and not expect any other settler to employ them and this I believe is the sort of unwritten law or mutual agreement between the settlers' (Mount Gould police letter book, 22 August 1892).

\section{THE LEGISLATION OF 1892}

Western Australia gained a fully elected parliament in 1890 yet there was no amelioration in the legislation, in fact, it became harsher. The Aboriginal Offenders (Amendment) Act 1892 authorized whipping and the Aborigines Protection Act (Amendment) Act 1892 extended the effective range of a warrant from 30 miles to 50. Robert Sholl the Member for the Gascoyne moved a motion that the government: 'take prompt and efficient measures to protect the lives and property of the settlers in that locality' (WA Parliamentary Debates, 14 January 1892, p. 244). Sholl explained that the devastating effect of a severe drought was compounded by the depredations of Aborigines killing the stock and if settlers had the courage to venture into these regions, they deserved the protection of the police.

Everard Darlot, now the Member for the Murchison, condemned the 30 mile condition of the 1886 legislation: 'A native may abscond from the home station of a squatter, and he only has to walk 30 miles away to be safe from arrest. He may still be on the settler's run, but his master cannot touch him' (WA Parliamentary Debates, 14 January 1892, p. 248). There was, he said, 'a regular organised gang' led by 'a notorious aboriginal gentleman from the Swan River' killing stock and robbing huts throughout the region. He was not satisfied with Rottnest and told of his surprise when he met with 15 men recently released from Rottnest whom he recognised as men he had sentenced at Beringarra the previous year. After their discharge, they were shipped to Geraldton, given a supply of flour and clothing and left to find their own way home, some $550 \mathrm{~km}$ to the north-east. When sentenced at Beringarra, Darlot continued, they 'were simply miserable specimens of humanity, but when I passed them near Mullewa they were all sleek and fat. Each man had a very nice shirt on him, and on his head $10 \mathrm{lbs}$ or $12 \mathrm{lbs}$ [pounds] of flour.'

Pastoralist Bernard Clarkson, the Member for Toodyay, agreed with Darlot. Rottnest was a pleasure trip and the institution should 'be wiped out altogether'. Those, like himself, who had experience with Aborigines knew: 'that there is only one way of keeping them in order, and that is by instilling them with fear' (WA Parliamentary Debates, 14 January 1892, p. 250). Timothy Quinlan, a Tipperary born publican, suggested that the government should come to an arrangement with Beagle Bay Catholic Mission, north of Broome, and send all Aboriginal offenders to that region. George Simpson, the Member for Geraldton regarded Rottnest as a 'most grandmotherly thing' and made the infamous comment: 'I think it will be a happy day for Western Australia and for Australia at large when the natives and kangaroos disappear,' (WA Parliamentary Debates, 14 January 1892, p. 256).

John Forrest defended the police and blamed the depredations on neglect and poor management. Citing Nookawarra station where sheep were unprotected and the owners had signed up workers and then neglected to feed them, he reminded Members that the drought had affected both the sheep and the natural game the Aborigines relied upon and their own needs caused them to kill sheep for food. He singled out Robert Bush JP, MP, a man with pastoral leases in the Upper Gascoyne and Upper Murchison running more than 10,000 cattle and 100,000 sheep, as one who complained the loudest, yet had left his sheep without a shepherd to protect them. The Upper Gascoyne and Upper Murchison was serviced by 15 police and 11 native constables. In the year up to 1 January 1892, 216 Aboriginal men had been arrested, but many were discharged upon arrival at Carnarvon because the pastoralists who laid the charges were not present to give evidence (WA Parliamentary Debates, 14 January 1892, p. 258-259). The removal of 216 men from one area must have had a devastating impact upon the Indigenous economy, family life and cultural maintenance.

On 29 January 1892, Attorney General Septimus Burt asked for a second reading of an amendment to the Aborigines Protection Act 1886 that became known as the 'Whipping Act'. He praised those pastoralists who, rather than taking matters into their own hands, had appealed to the government to check the destruction of stock and the attacks upon settlers. He agreed that Rottnest was a place

\footnotetext{
${ }^{7}$ Employment contracts continued until 1905 when the Aborigines Act, 1905 required individual permits for small numbers of Aboriginal employees and a general permit for pastoral station employment.
} 
where Aborigines grew fat and were then released to re-offend, and he insisted that the only way to deal with Aborigines - as with Chinese and Indians - was to whip them like naughty children, (WA Parliamentary Debates, 29 January 1892, p. 399). The number of lashes, limited to 25 for an adult male and 12 for youths below the age of 16 years, could be imposed by a single Justice if none other was closer than 20 miles, and might be in addition to a prison sentence. The whipping had to be carried out under the supervision of a Justice, a police officer not below the rank of sergeant, or a Protector of Aborigines. Absconders could not be whipped. Marinus Canning was opposed to flogging but, as there was no dissenting motion, the Bill moved on to the Legislative Council and passed into law.

Less than two months later, Leonard Darlot JP of Beringarra sentenced all 14 prisoners before him to 12 to 25 lashes to be administered by the police in his presence (Mt Gould police occurrence book, 2 April 1892). This suggests that some were under 16 years. Later that year in the same district, Budicoroo was convicted on two charges of breaking into a store and of stealing sheep. He was given 25 lashes by Constables Hackett, Riley and Hall and then released (Mt Gould police occurrence book, 11 August 1892).

Sir Alex Onslow, again the Administrator, signed the 1892 Act, but the incoming governor, Sir William Robinson, in a report to Lord Rippon, the Secretary of State for Colonies, expressed his concerns at the indiscriminate use of flogging. He referred to the case of Coorapompia @ Coorabombine who was sentenced by Robert Bush MP and Leonard Darlot to two years on Rottnest and 25 lashes. The governor was concerned that as no instrument of punishment was defined by law, Justices and magistrates allowed sticks to be used, resulting in brutal floggings. Police Inspector Troy, on two occasions, visited locations where men sentenced by Bush were tied to a rail fence and flogged insensible; the ground littered with stubs of sticks broken on the backs of the prisoners (Robinson to Lord Rippon, 6 October 1892, cited in Western Australian Votes and Proceedings 1892, paper No. 11). Following Troy's report Bush resigned as a Justice but continued as a member of the Legislative Council until 1893.

One concern in the outback was who was to do the flogging? When Rosco, aged about 20 years, attempted to steal a sheep at Peak Hill, he was sentenced to six months gaol and 20 lashes and packed off to Geraldton. Octavius Burt, the Comptroller of Prisons considered the sentence excessive: 'I think very strong reasons are necessary to justify the use of the "cat" in the case of an Aboriginal native where it would not be used if the offender was a white man,' (Prisons 2911/1903).
Nevertheless, a 'cat' was sent from Fremantle and the junior warder was ordered to administer the whipping in the presence of a doctor.

Willie Matico was a Murchison man sentenced to two years at Rottnest and 12 lashes to be given along the way. As no police or warder accepted the task he arrived at Rottnest with the whipping deferred until his release. Octavius Burt again intervened. He considered that a string of charges had been 'mercilessly piled up' in order to get the maximum conviction and to hold a flogging over a prisoner for two years was inhumane. The Attorney General agreed and in September 1904, the Minister for Justice, Robert Hastie, remitted Matico's sentence (Prisons 361/1904).

\section{CONCLUSION}

In 1841, Governor John Hutt legislated for Rottnest to become a prison island where men and boys would be trained in farm skills and placed into employment on the mainland. Five years later, Acting Governor F.C. Irwin removed most of the prisoners to labour gangs on public projects such as road making. With the arrival of Crown convicts in 1850, the need for Aboriginal labour diminished and in 1855 Governor Kennedy reopened Rottnest as a prison without rehabilitation. Well before the end of the century it was an expensive and inhumane failure.

The significant increase in men arriving at Rottnest from the Gascoyne and Upper Murchison regions seems to be attributable to a combination of draconian legislation, police practice which failed to separate suspected perpetrators from innocent spectators and a justice system that placed punishment and removal ahead of justice. The 1892 'Whipping Act', offered as an alternative to prison, seems to have been regarded by some pastoralist JPs as a welcome measure to inflict pain as well as punishment. In an ideal situation, Parliament would have acted to protect Aborigines from unjust practices. Instead, men such as Bush and the Darlot brothers demanded that severe punishments be written into the law and set the parliamentary mood for unjust legislation to continue into the 20th century with Acts such as the Aborigines Act 1905 passing through both houses with little more than token opposition. In 1902, the tourist potential of Rottnest Island was paramount, the Aboriginal Establishment was closed and the remaining prisoners transferred to regional prisons. A section of the island became an annex of Fremantle Prison and, until 1931, a small number of Aboriginal and non-Aboriginal men on good behavior or from remote localities, served short terms on the island employed on road maintenance, wood chopping and general duties. 


\section{REFERENCES}

Biskup, P. (1973). Not Slaves, Not Citizens: the Aboriginal Problem in Western Australia 1898-1954. University of Queensland Press: St. Lucia.

Forrest, J. (1884). Report of a Commission to Inquire into the Treatment of Aboriginal Native Prisoners of the Crown in this Colony. Legislative Council, Perth, 1884, Western Australian Votes and Proceedings 1885 Paper No. 32.

Forrest, K. (1996). The Challenge and the Change. Hesperian Press: Victoria Park.

Gill, A. (1977). Aborigines, settlers and police in the Kimberleys 1887-1905. Studies in Western Australian History 1: 1-28. Department of History, University of Western Australia: Nedlands.

Green, N. (1989). Aborigines of the Albany region 1821-1898. The Bicentennial Dictionary of Western Australians, Vol. VI. University of Western Australia Press: Nedlands.

Green, N. and Moon, S. (1997). Far From Home: Aboriginal Prisoners of Rottnest Island 1838-1931. The Bicentennial Dictionary of Western Australians, Vol. X. University of Western Australia Press: Nedlands.

Green, N. (1995). The Forrest River Massacres. Fremantle Arts Centre Press: Fremantle.

Green, N. and Moon, S. (1997). Far From Home: Aboriginal Prisoners of Rottnest Island 1838-1931. The Bicentennial Dictionary of Western Australians, Vol. X. University of Western Australia Press: Nedlands.

Green, N. and Moon, S. (1990). 'Aboriginal names of the South West c. 1841-1890'; 'Aboriginal names of the Murchison c. 1848-1890' and, in one volume, 'Aboriginal names of the Pilbara c. 1870-1890; the Gascoyne c1880-1890; the Kimberley c. 1880-1890'. Manuscript lodged with the Battye Library.

Hardie, J. (1980). Nor'Westers of the Pilbara Breed. Shire of Port Hedland: Port Hedland.

Hallam, S. and Tillbrook, L. (1990). Aborigines of the Southwest Regions 1829-1840. The Bicentennial Dictionary of Western Australians, Vol. X. University of Western Australia Press: Nedlands.

Hasluck, P. (1970). Black Australians. 2nd edition. Melbourne University Press: Melbourne.

McCorquodale, J. (1987). Aborigines and the Law: a Digest. Aboriginal Studies Press: Canberra.

McDonald, G.J.G. (1996). Beyond Boundary Fences. Hesperian Press: Victoria Park.

Morrow, E. (1937). The Law Provides. Herbert Jenkins: London.

Owen, C. (2003). 'The police appear to be a useless lot up there': enforcing the law in the East Kimberley. Aboriginal History 27: 105-130.

Pashley, A.R. (2000). Policing Our State: a History of Police Stations and Police Officers in Western Australia 18291945. Educant: Cloverdale.

Pedersen, H. and Woorunmurra, B. (1995). Jandamarra and the Bunaba Resistance. Magabala Books: Broome.

Pilmer, R.H. (1998). Northern Patrol: an Australian Saga.
Hesperian Press: Victoria Park.

Thomas, J.E. and Stewart, A. (1978). Imprisonment in Western Australia: Evolution, Theory and Practice. University of Western Australia Press: Nedlands.

Tindale, N.B. (1974). Aboriginal Tribes of Australia. University of California Press: Berkeley.

Roth, W.E. (1905). Report of a Royal Commission on the Condition of the Natives, Western Australian Votes and Proceedings 1905, Paper No. 5.

Russell, E. (1980). A History of the Law in Western Australia and its Development from 1829-1979. University of Western Australia Press: Nedlands.

Somerville, W. (1949). Rottnest Island. Rottnest Board of Control: Rottnest.

Western Australian Government Gazette, 17 December 1850 , Land Regulations.

Western Australian Government Gazette, 24 August 1864, Land Regulations.

WA Parliamentary Debates, 13-19 April and 18 July to 8 September 1883.

WA Parliamentary Debates, 21 June to 2 September 1886.

WA Parliamentary Debates, 19 August 1886.

WA Parliamentary Debates, 14 January 1892, p. 244.

Western Australian Votes and proceedings, 1887, Paper No. 5.

Western Australian Votes and proceedings, 1892, Paper No.11.

\section{ARCHIVES INTHE STATE RECORDS OFFICE OF WESTERN AUSTRALIA [SROWA]}

Beringarra police station, bush occurrences 3 January 1885 to 19 March 1890. SROWA Acc 735/3, Police Department files

CSR 1882, SROWA, Acc 527. Colonial Secretary's Office, correspondence files.

CSR 445/1885. ibid.

CSR 6141/1884. ibid.

CSR 6164/1884. ibid.

CSR 4925/1885. ibid.

CSR 1126/1886. ibid.

CSR 2712/1886. ibid.

CSR 542/1886. ibid.

CSR 4465/1887. ibid.

CSR 4170/1887. ibid.

CSR 2171/1887. ibid.

CSR 827/1889. ibid.

Mount Gould police letter book 1892. SROWA Acc 734/3, Police Department files

Mount Gould police occurrence book 1892. SROWA Acc 734/1, Police Department files

Police 28/307/1879, SROWA, Acc 430, Police Department files. Police 1590/1887. ibid.

Prisons 684/1899. SROWA, Acc 968, Prisons Department files. Prisons 2911/1903. ibid.

Prisons 361/1904. ibid.

MANUSCRIPT RECEIVED DECEMBER 2006; ACCEPTED FEBRUARY 2007. 